\title{
The website design and Internet site marketing practices of upscale and luxury hotels in Turkey
}

\author{
Seyhmus Baloglu ${ }^{\mathrm{a}, *}$, Yakup A. Pekcan ${ }^{\mathrm{b}}$ \\ ${ }^{a}$ Department of Tourism and Convention Administration, William F. Harrah College of Hotel Administration, University of Nevada, Las Vegas, 4505 \\ Maryland Parkway, Box 456023, Las Vegas, NV 89154-6023, USA \\ ${ }^{\mathrm{b}}$ Tourism and Hotel Management Department, School of Applied Technology and Management, Bilkent University, Bilkent, Ankara 06800, Turkey
}

\begin{abstract}
Internet with current and emerging multimedia features provides ample opportunities and particularly useful for dealing with intangible nature of the service, and transforming marketing mix variables to capitalize on the informational and transactional potential of the Internet, and to gain a competitive advantage. This study utilizes content analysis to analyze the websites of a select group (4- and 5-star) of hotels in Turkey in terms of site design characteristics (interactivity, navigation, and functionality) and site marketing practices on the Internet. This study also investigates variations in design and use of marketing elements on the Internet based on hotel type (4- and 5-star resort and transient hotels). The findings showed that the hotels in Turkey are not utilizing the Internet to its full potential and effectively e-marketing their hotels regardless of the hotel type.
\end{abstract}

(C) 2004 Elsevier Ltd. All rights reserved.

Keywords: Internet marketing; Web design; Turkey; 4- and 5-star hotels; Correspondence analysis

\section{Introduction}

According to global Internet usage statistics published by Convea organization, there are currently 619 millions of people who have access to Internet and this number is estimated to be 940 millions in 2004 (Convea, 2003). Turkey is a potentially large Internet market with 65.7 million inhabitants and geographic and economic links to both Europe and the Middle East. A report in 2000 has shown that in the last two years Turkey had the fastest growth in Internet usage in the World (Turkish Press Review, 2000; Pastore, 2001). Trends indicate that Internet usage will continue to grow significantly in the coming years. Most recent reports indicate that $20 \%$ of the population in Turkey are Internet users, up from $16 \%$ in 2001 (The European Travel Commission (ETC), 2002).

\footnotetext{
${ }^{*}$ Corresponding author. Tel.: + 1-702-895-3720; fax: + 1-702-8954870 .

E-mail addresses: baloglu@ccmail.nevada.edu (S. Baloglu), pekcan@tourism.bilkent.edu.tr (Y.A. Pekcan).
}

Contrary to Van Hoof \& Combrink (1998) findings, Parets (2002) suggests that smart Internet marketing is not just for big hotel chains and adds that the websites that are well-designed and easy to navigate provide independent or small hotels with an inexpensive and effective platform for marketing and advertising, which potentially increase their competitiveness in the marketplace. According to InternetWeek's survey, more than two-thirds of the travel and hospitality companies view the Internet site as a significant competitive weapon within their industry and about 60 percent describe the Internet as being substantial in acquiring new customers (Mullen, 2000). To use the Internet to its fullest potential and keep up with new technology, hotel companies continuously redesign their websites for ease and convenience, and upgrade web technology to make their Websites more personalized for customers. They also initiate web campaigns, develop brands and integrate branding strategy on the web, gather customer information, improve customer service, and streamline online reservations. (Connoly, Olsen, \& Moore, 1998; Mullen, 2000; Karpinski, 2001). 


\section{The purpose and conceptual framework}

This study utilizes content analysis to analyze the websites of a select group of hotels in Turkey in terms of site design characteristics (interactivity, navigation, and functionality) and marketing practices on Internet. The study also investigates variations in site design and use of site marketing elements on the Internet based on hotel type (4- and 5-star resort and transient hotels). Although a few similar studies have been conducted in other countries such as Australia, Greece, and Taiwan (Benckendorff \& Black, 2000; Sigala, 2001; Wan, 2002), there is very limited, if any, research on website design and practices of hotels in Turkey.

The research in the hospitality and tourism have demonstrated that the website design and Internet marketing features contribute to effective delivery of messages, quality of products and services, and brand image (Perdue, 2001). Several website content analyses studies have also shown that tourism organizations in Australia and hotels in Greece and Taiwan are not effectively using the Internet for web-based marketing and e-commerce (Benckendorff \& Black, 2000; Sigala, 2001; Wan, 2002).

Internet with current and emerging multimedia features provides ample opportunities and is particularly useful for dealing with intangible nature of the service and transforming marketing mix variables to capitalize on the informational and transactional potential of the Internet. The most common marketing practices include the transforming marketing mix (promotion, distribution, product and service, and price) variables and tangibilizing the hotel offerings (pictures, videos, etc.). (Wan, 2002; Kasavana, 2002; Sigala, 2001; Liebmann, 2000; Rushmore, 2000; Benckendorff \& Black, 2000).

The conceptual framework to assess website effectiveness in this study was built upon the work of Benckendorff and Black (2000), and complemented by other similar works and literature in trade and academic journals covering effective site design and e-marketing (Sigala, 2001; Wan, 2002; Kasavana, 2002; Liebmann, 2000; Rushmore, 2000). Since the overall quality of a website will influence the traffic and level of business (Liebmann, 2000), the design, content, and management of website should be taken into consideration for successful e-marketing (Legohérel, Fischer-Lokou, \& Guéguen, 2002). Site design characteristics include three major categories: interactivity, navigation, and functionality while the categories may not be mutually exclusive (Benckendorff \& Black, 2000).

\section{Methodology}

Hotel Guide 2002 (2003) published by Ekin Yazılım was used to identify the hotels to be analyzed. The guide has listed 220 4- and 5-star hotels in Turkey. Only 77\% of those hotels (169) had their website address listed. There were several hotel chains located in different cities of Turkey that were using the same website. This reduced the total number of sites to be content-analyzed to 139 . The majority of the hotels are located in the cities of Antalya, Muğla, and İstanbul, which are well-known tourist destinations of Turkey. Of the 139, ninety-three were 5 -star hotels while 46 were 4 -star hotels. The study also categorized these hotels into resort or transient hotels. This further classification resulted in four hotel types: 25 4-star resort $(18 \%), 21$ 4-star transient $(15.1 \%), 60$ 5-star resort $(43.2 \%)$, and 33 5-star transient hotels $(23.2 \%)$. A structured form, consisting of 45 checkpoints, is developed to assess the contents of the hotel websites (See Appendix). As the site performance may be influenced by the type of browser, computer speed, Internet speed, and time of a day, these external factors were controlled when conducting the content analyses of the sites, i.e. same browser, pentium 4 computer, high-speed Internet connection, and time slot of the day.

Data analyses were conducted by using SPSS 11.5. Multiple correspondence analysis (MCA) was utilized to represent the relations between hotel types and site design and marketing characteristics (ANACOR 4.0 procedure available with SPSS 11.5). MCA is an interdependence technique suited for analyzing multiple categorical data, simultaneously. A set of objects and attributes can be displayed graphically in a joint space to demonstrate the relations among row and column variables, which can hardly be revealed by multiple pair-wise comparisons (Hair, Anderson, Tatham, \& Black, 1998; Weller \& Romney, 1990). It is important to note that for CA to make sense, the Chi-square tests should be significant. Otherwise, there would be no significant association to describe (Weller \& Romney, 1990). Therefore, series of chi-square analyses were conducted to identify the variations (dependencies) in site design and marketing-related items based on hotel type. Once the significant variations were detected, the tables were aggregated in a multi-way matrix form to be used as input matrix for MCA. Multivariate analysis of variance (MANOVA) was also utilized to understand the variations in the number of items used in each category (interactivity, functionality, navigation, and marketing) due to hotel type. To accomplish this, summated scores for each category were calculated by adding the 'Yes' scores (coded as 1) in each category.

\section{Findings and discussion}

The descriptive statistics regardless of the hotel type showed that over $60 \%$ of the hotel websites tangibilize the service by including hotel and room pictures and 
using quality pictures and texts. Again, two-thirds of the hotels performed well in consistent navigation, ease of navigation, and ease of physical access to their websites. On the other hand, about $75 \%$ of the analyzed hotel websites performed poorly in terms of online information request form, calendar for special programs, online comment form, links to other sites, www links, promotions, online payment, links to tourist information, audio features, date last updated, and banner advertisement. More than $70 \%$ had a lengthy first page that you need to scroll down, and lacked features such as download facilities and new updates (what's new) on their websites. Only $10-15 \%$ of the hotels had online guest book, updated exchange rates, and banner advertisements. Less than $5 \%$ of the hotels provided search capabilities and online survey for their guests. These results indicated that the hotels are relatively performing well in navigation. However, their performances in interactivity and functionality were questionable. In general, from the marketing standpoint, most hotels were focusing on tangibilizing their offerings, but not effectively utilizing marketing mix variables on their websites, suggesting that the hotels were focusing on the basic and simple features of the Internet.
The chi-square analyses were used to identify the similarities and differences in site design and marketingrelated items across four hotel types. Of the 45 items, 28 were significant at 0.05 level. These items were then arranged in a multi-way matrix form, rows being 25 items, and columns being four hotel types, as an input matrix for MCA. The perceptual map and attributes were shown in Fig. 1. A two-dimensional solution was found more appropriate as they explained $89.9 \%$ of the variance. The singular values (eigenvalues) of the dimensions were 0.237 and 0.20 , meeting the 0.20 criteria for meaningful dimensions (Hair et al., 1998). The first dimension explained $53.3 \%$ of the variance while the second dimension explained $36.6 \%$ of the variance.

As shown in Fig. 1, the most frequently used features used in websites of the 4-star resort hotels involved reservation by e-mail, online reservations, multi-lingual capabilities, and phone numbers. Their sites also provided consistent navigation for the users. The most distinguishing characteristics of the websites of 5-star resort hotels were a variety of information in large quantity and details, e-mail for further information, background image and flash animation. Their websites

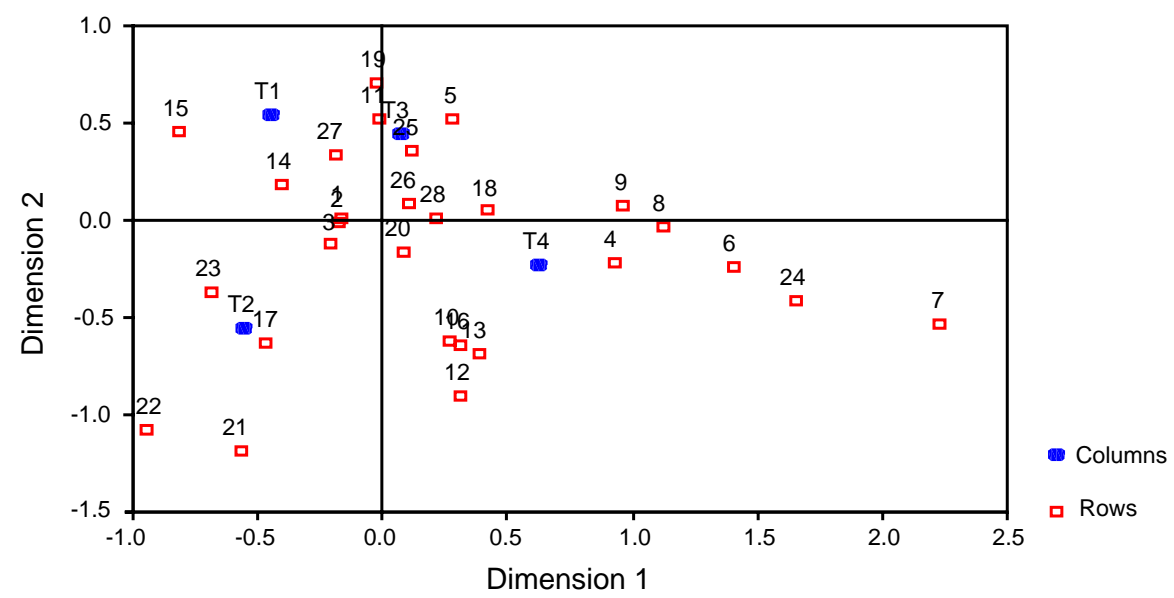

\begin{tabular}{|ll|ll|}
\hline T1 & 4-Star Resort Hotels & 13 & Any Promotion Mentioned \\
T2 & 4-Star Transient Hotels & 14 & On line Reservations \\
T3 & 5-Star Resort Hotels & 15 & Reservation by E-mail \\
T4 & 5-Star Transient Hotels & 16 & Links to Tourist Information \\
1 & Phone Number Listed & 17 & Availability of Price Info \\
2 & Address Listed & 18 & Corporate Identity \\
3 & E-mail Hyperlink & 19 & Background Image \\
4 & Online Information Request Form & 20 & Video \\
5 & E-mail Listed & 21 & Date Last Updated \\
6 & Exchange Rate & 22 & Download Facilities \\
7 & Online Survey & 23 & Ease of Download \\
8 & Online Comment Form & 24 & What's new? \\
9 & Online Guest Book & 25 & Variety of Information \\
10 & Links to Other Sites & 26 & Detailed Information \\
11 & ConsistentNavigation & 27 & Multilingual Capabilities \\
12 & www Links & 28 & Flash Animation \\
& & & \\
\hline
\end{tabular}

Fig. 1. The correspondence analysis joint map. 
included the corporate identity and navigation was consistent. On the other hand, the 5-star transient hotels mostly included features such as online information request form, web links, links to other sites, and tourist information. They were more likely to mention promotional offers and use videos to tangibilize their offerings. Although most of the hotel websites did not include the features such as online survey, online guest book, what's new, and exchange rate information, the 5-star transient hotels were more likely to offer these features in their websites. The 4-star transient hotels were more likely to provide price information and easy download facilities. Despite the fact that they offered price information and displayed the update dates, they were found 1-2 yr old.

Some of the differences were related to hotel type and clientele (business vs. pleasure). For example, 5-star resorts enhance their websites with images and flash animation to reflect the vividness of the destination. However, it should be noted that most of the differences should not have existed at all because effective site design and e-marketing are necessary for all hotel types. Interestingly, 4-star resort hotels were found to offer more multi-lingual capabilities compared to 5-star resort and transient hotels.

Lastly, MANOVA with Tamhane post-hoc tests were utilized to see which category of items are focused and emphasized by the hotel types (Table 1). The overall MANOVA tests of Pillais and Wilks's Lambda were significant $(p<0.0001)$, which suggested to reject the null hypothesis that mean vectors of site design and marketing categories across the hotel types are the same. The mean scores show that the hotels included in this study exhibited very limited use of site design and marketing category items regardless of the hotel type. For example, for interactivity the 5-star transient hotels only use an average of 5.7 items out of 10 items in this category. The results show that all categories are significantly different across the hotel types. Overall, 5-star transient hotels were found performing better than other type of hotels in terms of site design and marketing features included in their websites.

The 4- and 5-star resort hotels in Turkey mostly rely on tour operators and travel agents, which may partially explain the lack of marketing features in their websites. However, domestic tourism is substantially increasing. Between January and April, 2003, the lodging companies in Turkey have spent $\$ 3.7$ million for advertising to the domestic market, a $16 \%$ increase from the 2002 figures. For the first time, hotel promotion advertising for local market has exceeded those of travel agents. This trend, coupled with the skyrocketed Internet usage statistics for Turkey, should urge upscale and luxury hotel properties in Turkey to redesign their websites accordingly to use full capabilities of the Internet for informational and transactional marketing practices. As the site design and marketing features on the Internet are strongly interlinked, further attention to interactivity, navigation, and functionality of their websites should also be given.

\section{Concluding comments}

In conclusion, the findings showed that hotels included in this study are not utilizing the Internet to its full potential and effectively marketing their hotels. Given the increasing popularity of Internet usage in Turkey and worldwide, they should take advantage of full range of features of the Internet for both site design-particularly for interactivity and functionality - and marketing mix variables. The sites could also be improved by value-added features such as weather conditions, updated exchange rates, destination links, and animation and graphics. A particular attention should be given to online guest comment or survey forms, search capabilities in the homepage, and adapting marketing mix variables to the Internet regardless of the hotel type. The early adoption of effective site design and marketing features might provide competitive advantage in the future when e-marketing becomes more popular in Turkey. The findings are limited to hotels listed in the 2002 Hotel Guide published in 2003, and to the web design and marketing items included in this study.

Table 1

MANOVA and post-hoc tests

\begin{tabular}{lllllll}
\hline Characteristics & $\begin{array}{l}\text { 4-Star resort } \\
(n=25)\end{array}$ & $\begin{array}{l}\text { 4-Star transient } \\
(n=21)\end{array}$ & $\begin{array}{l}\text { 5-Star resort } \\
(n=60)\end{array}$ & $\begin{array}{l}\text { 5-Star transient } \\
(n=33)\end{array}$ & $F$-value & $P$-value \\
\hline Interactivity (10 items) & $2.6 \mathrm{a}$ & $3.6 \mathrm{a}$ & $4.3 \mathrm{~b}$ & $5.7 \mathrm{c}$ & 13.2 & $0.000^{\mathrm{b}}$ \\
Navigation (7 items) & $3.3 \mathrm{a}$ & $4.0 \mathrm{a}, \mathrm{b}$ & $3.8 \mathrm{a}, \mathrm{b}$ & $4.5 \mathrm{~b}$ & 3.7 & $0.012^{\mathrm{a}}$ \\
Functionality (16 items) & $6.0 \mathrm{a}$ & $7.2 \mathrm{a}, \mathrm{b}$ & $8.2 \mathrm{~b}$ & $8.9 \mathrm{~b}$ & 2.9 & $0.036^{\mathrm{a}}$ \\
Marketing (12 items) & $6.6 \mathrm{a}$ & $8.5 \mathrm{~b}$ & $7.8 \mathrm{a}, \mathrm{b}$ & $7.7 \mathrm{a}, \mathrm{b}$ & 0.5 \\
\hline
\end{tabular}

Note: The cell figures are arithmetic means; mean scores with different letters are significantly different.

${ }^{\mathrm{a}} p<0.05$.

' $p<0.001$; Bartlett's Test of Sphericity=189.1 (9d.f., 0.000); Box's M=61.5 (0.002). 


\section{Appendix A. Internet Site Evaluation Form}

Site URL:

Hotel Type:

City:

Site Design Characteristics

$(1=$ Yes, $0=$ No $)$

\section{Interactivity}

Phone Number Listed

Address Listed

E-mail Hyperlink

Online Information Request Form

E-mail Listed

Navigation

Links to Other Sites

Links to other Revenue Centers

(hotel, restaurant, bar, etc.)

Consistent Navigation

Ease of Navigation

$\begin{array}{ll}1 \square & 0 \square \\ 1 \square & 0 \square \\ 1 \square & 0 \square \\ 1 \square & 0 \square \\ 1 \square & 0 \square \\ 1 \square & 0 \square \\ 1 \square & 0 \square \\ 1 \square & 0 \square \\ 1 \square & 0 \square \\ 1 \square & 0 \square \\ 1 \square & 0 \square \\ 1 \square & 0 \square \\ 1 \square & 0 \square \\ 1 \square & 0 \square \\ 1 \square & 0 \square \\ 1 \square & 0 \square \\ 1 \square & 0 \square\end{array}$

Calendar (for special programs)

Updated Exchange Rate

Online Survey

Online Comment Form

Online Guest Book

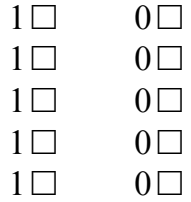

Functionality

Corporate Identity

Background Color

Background Image

Video

Audio

Date Last Updated

Banner Advertisement

$1 \square \quad 0 \square$

www links (hyperlinks)

Index Page

Search Capabilities

$\begin{array}{ll}1 \square & 0 \square \\ 1 \square & 0 \square \\ 1 \square & 0 \square\end{array}$

Do you have to scroll down on first page?

Site Marketing Characteristics

$\begin{array}{lll}\text { Download Facilities } & 1 \square & 0 \square \\ \text { Ease of Download } & 1 \square & 0 \square \\ \text { What's New? } & 1 \square & 0 \square \\ \text { Variety of Information } & 1 \square & 0 \square \\ \text { Detailed Information } & 1 \square & 0 \square \\ \text { Multilingual Capabilities } & 1 \square & 0 \square \\ \text { Flash Animation } & 1 \square & 0 \square \\ \text { Ease of Physical Access to WebSite } & 1 \square & 0 \square\end{array}$

$(1=$ Yes, $0=$ No $)$

Hotel Picture

$1 \square \quad 0 \square \quad$ Location Map of the Hotel

Room Picture

$1 \square \quad 0 \square$

Online Payment

Quality of Pictures

$1 \square \quad 0 \square$

Quality of Text

$1 \square \quad 0 \square$

Any Promotion Mentioned

$1 \square \quad 0 \square$

Online Reservation

Reservation by E-mail

Description of Product and Services

Links to Tourist Information

Availability of Price Info

$\begin{array}{ll}1 \square & 0 \square \\ 1 \square & 0 \square \\ 1 \square & 0 \square \\ 1 \square & 0 \square \\ 1 \square & 0 \square \\ 1 \square & 0 \square\end{array}$

Comments:

\section{References}

Benckendorff, P. J., \& Black, N. L. (2000). Destination marketing on the Internet. A case study of Australian Regional Tourism Authorities. The Journal of Tourism Studies, 11(1), 11-21.

Connoly, D. J., Olsen, M. D., \& Moore, R. G. (1998). The Internet as a distribution channel. The Cornell Hotel and Restaurant Administration Quarterly, August, 42-54.

Convea (2003). Internet usage statistics. Retrieved November 15, 2003 from http://www.convea.com/resources_Internetusage.asp.

Hair, J. F., Jr., Anderson, R. E., Tatham, R. L., \& Black, W. C. (1998). Multivariate data analysis (5th ed.). Upper Saddle River, NJ: Prentice-Hall.

Hotel Guide 2002 (2003). Ekin Yazim: Istanbul, Turkey.
Karpinski, R. (2001). The Remodeling of Hilton: expansion into new chains and franchising made e-business an imperative. InternetWeek, 865, 29-36.

Kasavana, M. L. (2002). eMarketing: restaurant websites that click. Journal of Hospitality and Leisure Marketing, 9(3/4), 161-178.

Legohérel, P., Fischer-Lokou, J., \& Guéguen, N. (2002). Selling tourism on the Internet: analysis of the balance of power between seller and consumer during information exchange and negotiation. Journal of Tourism and Leisure Marketing, 9(13), 49-63.

Liebmann, L. (2000). Help for building sticky web sites. Information Week, 815, 158-164.

Mullen, T. (2000). Travel's long journey to the web. Internet Week, 835 , 103-106. 
Parets, R. T. (2002). Getting the word out: profiting from smart Internet marketing isn't just for the big boys. Lodging Magazine, August, 37-38.

Pastore, M. (2001). Turkish ISP subscribers boom in 2000. Retrieved November 15, 2003 from http://cyberatlas.Internet.com/ big_picture/geographics/article/0,5911_574601,00.html.

Perdue, R. R. (2001). Internet site evaluations: the influence of behavioral experience, existing images, and selected website characteristics. Journal of Travel \& Tourism Marketing, 11(2/3), 21-38.

Rushmore, S. (2000). Internet 101: introduction to building a hotel website. Hotels, 34(4), 44.

Sigala, M. (2001). Modeling e-marketing strategies: Internet presence and exploitation of Greek hotels. Journal of Hospitality and Tourism Marketing, 11(2/3), 83-97.
The European Travel Commission (ETC) (2002). New media review. Retrieved October 23, 2003 from http://www.etcnewmedia.com/ review/default.asp?SectionID $=11 \&$ CountryID $=90$.

Turkish Press Review (2000). Internet usage snowballing. Retrieved November 10, 2003 from http://www.hri.org/news/turkey/trkpr/ 2000/00-08-15.trkpr.html\#08.

Van Hoof, H. B., \& Combrink, T. E. (1998). US lodging managers and the Internet: perceptions from the industry. The Cornell Hotel and Restaurant Administration Quarterly, 39(2), 46-54.

Wan, C. S. (2002). The web sites of international tourist hotels and tour wholesalers in Taiwan. Tourism Management, 23, 155-160.

Weller, S. C., \& Romney, A. K. (1990). Metric scaling: correspondence analysis (Sage University paper series on quantitative applications in the social sciences, series no.07-075). Newbury Park, CA: Sage. 